\title{
8. Negotiating Community Support for Closure or Continuation of the Ok Tedi Mine in Papua New Guinea
}

COLIN FILER AND PHILLIPA JENKINS

\section{Introduction}

The Ok Tedi mine has some claim to be an extreme case of a large-scale mine whose closure is beset by politics. Ever since the mine began to operate in 1984, there has been ongoing political debate about whether its operations should continue and, if so, under what conditions. At several moments in its history-in 1985, 1989, 1996, 2001, 2006 and, most recently, 2013-the Papua New Guinea (PNG) Government has been obliged to confront this question directly, and on each occasion it has come down in favour of continuation. Nevertheless, the mining company has already begun to scale down its operations in preparation for closure by 2025 , if not before, because most of the ore contained in its original deposit of gold and copper has already been mined.

The political significance of the choice between closure and continuation is primarily a function of the mine's international reputation as an environmental disaster. The choice has therefore been represented as a 'trade-off between environmental costs and economic benefits. In 2005, at the peak of its output, it was estimated that this one mine was responsible for 15 per cent of PNG's gross domestic product, 
25 per cent of the country's export revenues and roughly 20 per cent of the tax revenues raised by the PNG Government (Faulkner 2005). The environmental costs are almost impossible to calculate.

When the PNG Government approved the start of mine construction in 1981, there were plans to store the waste material in containment facilities close to the mine site. But when a landslide halted work on these facilities in 1984, the mine's operator, Broken Hill Proprietary Ltd (BHP), sought to persuade the government that there was no safe method of storing this material without destroying the project's economic viability (Jackson 1993). Once this argument had been reluctantly accepted by the government, the mine proceeded to discharge its waste material into the Alice (or Ok Tedi) River. The effects of this practice were magnified in 1987, as the mine began to produce large quantities of copper in addition to the gold that was its first target, and the volume of waste material increased accordingly. The mine was soon discharging more than 80 million tonnes of tailings and waste rock into the Alice River each year, and a growing proportion of this material was finding its way into the Fly River, more than 100 kilometres south of the mine site. The consequential damage to local ecosystems has been the subject of numerous scientific studies whose content we do not propose to summarise. But as the mine continued to operate, and these studies continued to accumulate, so the terms of the trade-off began to change. The longer the mine continued to operate, the more time it would take for local ecosystems to recover from the damage it had caused, but the longer it continued to operate, the more time and money the operators could spend on finding the best ways and means to limit the extent of this damage.

The trade-off between the economic benefits and environmental costs of the Ok Tedi mine has sometimes been represented as a dilemma for the PNG Government, rather than other stakeholders, or as a trade-off between benefits to the nation as a whole and costs to the people of the mine-affected area-especially the area downstream of the mine where the level of environmental damage has been most acute. But matters are not quite so simple. The PNG Government has certainly experienced an enduring conflict of interest as a result of its triple role as the mine's regulator, tax collector and joint venture partner (Jackson 1982; Pintz 1984). This means that different agencies or ministries within the national government have taken different positions on the question of continuation when the question has been raised. When the mine was first developed, $\mathrm{BHP}$ and the other private partners in Ok Tedi Mining Ltd (OTML) may 
well have discounted the mine's environmental costs in comparison with the profits to be made for their own shareholders, but the environmental costs became reputational costs before the profits from operation of the mine could offset the cost of its construction. BHP stopped operating the mine in 2001 because the company's directors had come to see it as a political and economic liability for which no future profits could compensate their shareholders. But the people of the mine-affected area could not remove themselves from either the costs or the benefits of the mine by means of such a calculated judgment. Throughout the period of its operation, these people have received a growing share of the economic benefits the mine has produced for the nation, even while many have suffered from the growth of its environmental costs. So if the national government has persistently discounted these local costs in the name of a greater national benefit, this does not mean that local stakeholders can equally discount the local benefits of the mine when they protest against the government's neglect of its environmental obligations.

There is another form of government neglect that has served to accentuate the dependency of the mine-affected area on the continued operation of the mine. This consists in the long-standing failure of the Fly River Provincial Government to use its own share of mine-related benefits to provide public goods and services to the people of Western Province as a whole, including that half of the provincial population which officially lives in the mine-affected area (Burton 1998). The PNG Government has generally done very little to discourage mining companies from assuming this type of public function, but the Ok Tedi mine has produced a 'proxy state' which is larger and more complex than others of its kind, and might even hold a world record to match its more familiar global reputation for polluting the natural environment. The size of this proxy state has grown in step with the size of the mine-affected area and the various agreements made to compensate some of its residents for the environmental damage caused by the mine. But its complexity was also enhanced by the specific set of agreements which enabled the mine to keep operating after BHP had stopped operating it.

Under the terms of the Mining (Ok Tedi Mine Continuation [Ninth Supplemental] Agreement) Act 2001, BHP Billiton (as it had then become) transferred its 52 per cent stake in OTML to a corporate body that was registered in Singapore as PNG Sustainable Development Program Ltd (SDP). This body was required to act like a cross between a provincial government, an international aid agency and an intergenerational trust 
fund. So long as the mine continued to operate, SDP would invest twothirds of its net income from the mine in a 'long term fund' that would be used to mitigate the negative impacts of mine closure for a period of 40 years after the mine had closed and, in the meantime, would put the remaining third of its net income into a 'development fund' to be spent on 'sustainable development projects' in PNG. Sustainable development projects in Western Province would account for one-third of the spending from the 'development fund', while the other two-thirds would be spent in other parts of PNG.

The Ninth Supplemental Agreement also required OTML to establish and fund a body known as the Ok Tedi Development Foundation (OTDF). This was the successor to a body known as the Lower Ok Tedi/Fly River Development Trust, which was established under the terms of a previous agreement made with the PNG Government in 1989. Like SDP, the new body had a broad mission to 'promote equitable and sustainable social and economic development' in the whole of Western Province, but its funding was primarily meant to benefit those mine-affected communities whose members would agree to relinquish their rights to sue BHP or the PNG Government for any additional compensation for the damage caused by the mine. In effect, OTDF became the vehicle through which OTML assumed responsibility for the management of a complex web of compensation and benefit streams earmarked for the people of the mine-affected area under a set of agreements that was already growing before 2001 and has continued to evolve since then. At various points in time, it has also been the vehicle through which OTML has managed the spending of government money earmarked for the people of this area or the rest of Western Province.

While BHP was happy to wash its hands of the Ok Tedi mine in 2001, SDP had a vested interest in keeping the mine open as long as possible so long as it made a profit. By 2010, SDP held 63.4 per cent of the shares in OTML. The balance was held by the PNG Government, half of which was held in trust for Western Province stakeholders, including the Fly River Provincial Government. The SDP stake yielded a net income of roughly US\$1.8 billion between the start of 2001 and the end of 2012 . If the mine continues to operate until 2022, the 'long term fund' could be worth US $\$ 3.7$ billion when it closes (Howes and Kwa 2011). However, the profits which grew from the rise in copper prices over the period since 2001 created a predictable dilemma for this arm of the Ok Tedi proxy state. The greater its apparent wealth and power, the greater the incentive 
for the national and provincial governments to challenge its apparent lack of accountability to anyone except its own board of seven directors, only two of whom were government nominees. In 2013, the PNG parliament passed a bill which made it government property, and thus turned the mine into a wholly state-owned enterprise.

It is not our intention to explore the whole political process that led to this act of expropriation, but rather to understand how 'local communities' have come to be engaged in the political process through which the question of mine closure continues to be addressed. In a paper written many years ago, John Burton argued that OTML (or BHP) was taken by surprise when an environmental protest movement first emerged in the mine-affected area, because 'politics' was a less significant feature of traditional culture in this area than it was in many other parts of PNG (Burton 1997: 33). At the same time, Stuart Kirsch argued that this protest movement 'gave rise to a new generation of political leaders who were able to transcend the traditional limits on power' (Kirsch 1997: 126). Both papers were published in a volume devoted to understanding the sequence of activities that led some local people to sue BHP for damages in an Australian court and eventually win an out-of-court settlement of their case in which BHP promised a substantial compensation package for people living downstream of the mine (Banks and Ballard 1997).

This sequence of activities was well under way by 1991, and the local leaders of the protest movement became international celebrities when the court case received extensive media coverage in 1994. It is a moot point whether they took the lead in mobilising their own local supporters, or whether the leaders themselves were mobilised or engaged by a coalition of national and international advocates for environmental justice and the rights of indigenous peoples (Filer 1997; Kirsch 2007). Kirsch thought that the lawsuit gave rise to new forms of social and political solidarity in the mine-affected area, but Burton noted that leaders of the protest movement won only a small fraction of the local vote in the national election of 1997, and put this down to the persistence of an 'apolitical' culture: 'With few connected traditional political structures above the lineage they had little chance of binding people together into viable political voting blocks, no matter how well-known they were' (Burton 1997: 53).

The question we address in this chapter is the question of how power has been distributed and redistributed between 'local communities' and the other stakeholders involved in making the choice between closure 
and continuation of the Ok Tedi mine. Our main focus is on the way that this choice has been framed in the period since the legal foundations of the company's operations were amended in ways that placed the representation of mine-affected communities at the heart of this political and economic choice.

\section{To Close or Not to Close: The Context of the Ninth Supplemental Agreement}

The out-of-court settlement agreed in 1996 said that BHP and the 'claimants' who had taken it to court would commit to the implementation of any 'tailings option' proposed by the PNG Government provided that BHP regarded it as 'economically and technically feasible' (Banks and Ballard 1997: 216). What actually happened was that OTML commissioned a series of technical reports under the terms of its Mine Waste Management Project and summarised their findings in the form of a 'risk assessment' that was presented to the PNG Government in 1999 (OTML 1999). In this report, the risks were attached to four alternative courses of action that could be taken in light of the fact that OTML had already initiated a 'trial river dredging program' in the lower reaches of the Alice River in order to shift some of the waste material from the river-bed to the river banks. The first option was to keep mining and keep dredging until the 'scheduled end of mine life' in 2010; the second was to stop dredging but keep mining until the point of mine closure; the third was to keep mining and build a new tailings dam by 2001 as an alternative to riverine tailing disposal; and the fourth was to close the mine in 2000 .

The report recognised that none of these four options would put a halt to the environmental damage caused by the previous deposition of waste material into the Alice River. It was predicted that the Fly River catchment would continue to sustain such damage for decades after the mine closed, regardless of whether it closed in 2000 or 2010 . BHP's preference was to close the mine sooner rather than later, because the first and second options would still cause more environmental damage than the fourth option, while the economic cost of implementing the third option would not produce enough environmental benefits to make it economically worthwhile (Sharp and Offor 2008: 3). Some of the plaintiffs in the previous court case then decided to sue BHP for breach of contract in discounting the feasibility of the third option (Kalinoe 2008: 7), but BHP 
had already declared that continued operation of the mine would be inconsistent with its own 'environmental values', which had apparently been reconstructed over the course of the previous three years. ${ }^{1}$

This placed the PNG Government in a familiar quandary. This time the government hedged its bets by asking the World Bank to review the risk assessment report and provide a review of the 'independent reviews' already commissioned by OTML. The bank's reviewers agreed that immediate closure was the best option from an 'environmental standpoint', but 'from a social standpoint this would result in a potentially disastrous situation because there is no preparedness for mine closure' (World Bank 2000: 8). They were also concerned by the lack of socioeconomic information in the various technical reports:

The complex social environment in which $\mathrm{Ok}$ Tedi is situated, exacerbated or arguably caused by the fact that Ok Tedi is the only agent of development in the Western Province, has meant that closure has multiple ramifications for the community impacted by its operations and for the government with whom overall responsibility rests for the welfare of its citizens. Thus, much more information is needed regarding the social and cultural history and characteristics of the communities affected by the [mine's] operations and the impacts need to be examined under four major aspects, namely consultation and participation of local communities; compensation; local distribution of benefits and related social, economic and cultural impacts; and employment impacts during and after mine operations. (ibid.: 16-17)

The reviewers therefore suggested that the government should engage in a process of public consultation in order to assess 'the political dimensions of the problem', and allow the mine to operate until a draft mine closure plan had been subjected to a social, as well as an environmental, impact assessment (ibid.: 20, 31).

For its part, OTML was still one step ahead of the government because its managers had already initiated the process of 'community consultation' when the risk assessment report was completed in 1999 (Kalinoe 2008). It was this process that resulted in the six Community Mine Continuation Agreements that were signed by the company's managers and local community representatives and attached as schedules to the

1 BHP's desire to wash its hands of the whole operation and avoid a new round of negative publicity may well have been a function of market pressures associated with its imminent merger with Billiton (Kirsch 2007: 309). 
Ninth Supplemental Agreement in 2001. These agreements contained a commitment by OTML to spend an additional K180 million to compensate the mine-affected communities over the remaining life of the mine or, more specifically, to compensate those communities whose representatives agreed to withdraw their support for the new lawsuit against BHP Billiton before the end of 2002 (Kalinoe 2008: 7). Fiftyeight per cent of the value of this new compensation package was to be provided in the form of 'development projects', while 16 per cent was to be paid in cash to community members and the remaining 26 per cent was to be held in trust for future generations, rather like the money that was due to accumulate in the 'long term fund' administered by SDP. Each of the six agreements contained a declaration that 'the economic opportunities offered by the Company's Commitments represent to the Communities an acceptable trade-off for the environmental impacts of the future operation of the mine', which was still expected to close in 2010.

\section{Political Constructions and Divisions of the Mine-Affected Area}

The problem of negotiating community support for any agreement relating to the closure or continuation of the Ok Tedi mine has grown more complex as the outer limits of the mine-affected area have expanded while the internal social and economic divisions of its population have deepened. The people who were invited to accept the trade-off postulated in the Ninth Supplemental Agreement were not simply the sons and daughters of the people who were regarded as members of mineaffected communities when the Mining (Ok Tedi Agreement) Act was passed in 1976, before the need for such a trade-off was envisaged. That first agreement between BHP and the PNG Government contained a pair of clauses which declared that the developers of the mine would, where 'practicable', give first preference in project employment and local business development to the landowners in and other people originating from the Kiunga and Telefomin sub-provinces'. The creation of this 'preferred area', which now comprises the North Fly District of Western Province and the adjoining Telefomin District of West Sepik Province, was not intended as a form of compensation for any sort of environmental damage, but as an extra benefit that was justified by the underdevelopment of this area in comparison with other parts of the country (Filer 2005). The 1980 national census, which was conducted before the start of mine construction, counted 38,440 people resident 
in this preferred area, nearly all of whom were rural villagers. Less than 3 per cent of these people qualified as 'mine area landowners' who would be compensated for the sacrifice of their customary land to the mine and its associated infrastructure, and only 1 per cent would receive a share of mining royalties because they were customary owners of the mountain that was going to be excavated (Filer 1997: 64).

The boundaries of the 'mine-affected area' were radically transformed when the Lower Ok Tedi/Fly River Development Trust was established in 1990 as a means to compensate communities downstream of the mine whose members were beginning to suffer the effects of riverine waste and tailings disposal. One hundred and two villages containing about 30,000 people were initially identified as beneficiaries of the trust. Nineteen of these villages were located in the 'Ningerum area', immediately south of Tabubil and the 'mine area villages', while another ten were located further south in the 'Alice area', along the lower reaches of the Alice (Ok Tedi) River, where the environmental damage was most acute. The traditional inhabitants of these 29 villages accounted for one-sixth of the trust's individual beneficiaries, but they also accounted for 8 per cent of the 59,337 people recorded as residents of the original 'preferred area' in the 1990 national census. In effect, the mine-affected area had now been divided between an 'upstream area', which contained the other 92 per cent of the people living in the original preferred area, and a 'downstream area', which contained the people entitled to a new form of compensation from the mining company.

But new forms of social division were also emerging within each of these areas. The downstream area was like a corridor passing a set of traditional cultural rooms or spaces whose occupants were now suffering different forms and degrees of damage to their natural environment, while the upstream area was more like a set of concentric circles (or semicircles) whose occupants had more or less access to the material benefits derived from the mining operation. The main axis along which the two areas were divided from each other was the road connecting the towns of Tabubil and Kiunga, which was the first stage in the route by which the products of the mine found their way to the world market. According to the census, these two towns had a combined population of 8,688 in 1990, and thus accounted for 15 per cent of the residents in the original preferred area. Many of the people living in these towns had been recruited from villages in the preferred area and were now dependent on cash incomes generated by the mining operation and its associated service economy. As a general 
rule, the cost of getting from a rural community to one of the two towns was inversely related to the number of its members who were able to obtain a share of such incomes.

New forms of social division were most acute in that part of the downstream area whose inhabitants were now suffering the most extensive damage to their natural environment. The indigenous inhabitants of the 'Alice area' were divided between two traditional cultures-the Yonggom people on the western side of the river and the Awin people on the eastern side. The Australian colonial administration encouraged the members of both ethnic groups to form larger settlements along the banks of the river in order to facilitate communication (by boat) with what was then the administrative outpost at Kiunga (Jackson 2003). Other members of the Awin group spontaneously formed new settlements along the route of the Tabubil-Kiunga road as mining plans were developed in the $1970 \mathrm{~s}$ (Jackson 1979), so the Awin people have since been divided between those in the upstream area (along the road) and those in the downstream area (along the river). The history of resettlement created a situation in which the members of Awin and Yonggom communities in the 'Alice area' were divided in the strength of their traditional claims to ownership of the land and resources that were now being damaged by mining operations, and hence to compensation for such damage (Kirsch 1995; Jackson 2003). Meanwhile, another form of social division was created when a large number of Yonggom refugees from the Indonesian province of Irian Jaya (or West Papua) took up residence on the PNG side of the border in 1984, thus creating additional pressure on the land and resources of the Yonggom people who were already living there (Kirsch 1989; King 1997). By 1990, migrants from traditional Yonggom and Awin villages had already established sizeable settlements in the town of Kiunga (King 1993), but the 'Alice people' who remained in their riverside villages suffered a degree of relative deprivation as the Tabubil-Kiunga road became the main economic axis of the North Fly region (Jackson 2003).

When the mine development agreements were renegotiated in 1990, provision was made for the mine area landowners to receive 30 per cent of the royalties collected by the national government, instead of the 5 per cent to which they were previously entitled, while the share allocated to the Fly River Provincial Government was correspondingly reduced from 95 to 70 per cent. This entailed a new degree of economic inequality among the people of the ten 'mine area villages', who then numbered about 2,200. The four villages containing the customary owners of the mine site would 
get 25 per cent of the royalties, while the village containing the customary owners of the mining town would get 5 per cent. Four villages would continue to receive rental payments for the land containing the tailings storage facility that was never built, but they were now being treated as part of the downstream 'Ningerum area', so the 'mine area landowners' were now understood to consist of about 1,500 people living in the other six villages.

Under the terms of these new development agreements, the Fly River Provincial Government also undertook to spend about half of its own revenues for the benefit of 'landowners in the project lease areas, along the Tabubil-Kiunga road, along the Ok Tedi-Fly River, and in the Fly River Delta area' (Jackson 1993: 71). This meant that people in the eastern part of the original area of preference in Kiunga (now North Fly) District were removed from the 'mine-affected area' within Western Province. Specific proportions of the new benefit package were earmarked for the mine area villages, the 'Alice villages' (including villages in the Ningerum area), the 'Highway villages', and the 'Middle Fly' and 'South Fly' villages. These proportions seem to have reflected the relative size of the respective village populations rather than the extent of environmental damage in each area (Filer 1997: 70). But this division of the mine-affected area was rather less significant than the one that accompanied the establishment of the Lower Ok Tedi/Fly River Development Trust because OTML already had far more capacity to deliver on its undertakings.

OTML adopted its own development program for the 'Highway villages' in 1995, but this was worth a great deal less than the Lower Ok Tedi Agreement that emerged from the out-of-court settlement of the Australian court case in 1997. The beneficiaries of this agreement were the residents of eight Yonggom villages and seven Awin villages in the 'Alice area' whose residents had claims over the land to be affected by OTML's trial dredging program. The distribution of compensation between these villages was to be a function of the size of their populations, the length of their respective riverside frontage, and the extent of the damage caused to the rest of their traditional territories (Banks and Ballard 1997: 207-10; Filer et al. 2000: 60-1). This compensation package was essentially a premium paid on top of the entitlement of all downstream communities to benefit from the development trust and to receive additional compensation under the terms of the Restated Eighth Supplemental Agreement concluded in 1995.

Between 1990 and 2000, the resident population in the downstream part of the mine-affected area increased by almost 100 per cent, from 30,000 to nearly 60,000 . This was partly due to a 40 per cent increase in the 
number of village communities that were included within its boundaries. The national census recorded a similar rate of increase in the combined population of Tabubil and Kiunga, which rose from 8,688 to 16,944, but this was partly due to in-migration, not to any change in the town boundaries. By 2000, the population of the six mine area villages near Tabubil had grown to about 2,300, while almost 50,000 people were living in other rural villages in the upstream part of the original preferred area, including Telefomin District in West Sepik Province. In its broadest definition, the mine-affected area therefore contained about 130,000 people, and accounted for roughly two-thirds of the population of Western Province alone.

A total of 149 village representatives signed the six 'community mine continuation agreements' (CMCAs) that were finalised in 2002. The six mine area villages made up one of the six 'CMCA trust regions'. The other five regions were North Ok Tedi (the Ningerum area), Lower Ok Tedi (the Alice area), the Highway, the Middle Fly and the South Fly (Kalinoe 2008: 19-20). When the CMCAs were reviewed and renegotiated in 2006, the number of trust regions grew from six to nine, as the South Fly region was divided into four parts (see Figure 8.1). There was a slight increase (from 149 to 156) in the number of village representatives who signed the new agreements because of a reduction in the number of villages whose representatives had refused to sign the previous agreements (Menzies and Harley 2012: 4).

An unofficial annual census conducted by OTML showed that the combined population of all the CMCA villages rose from 81,136 in 2007 to 101,413 in 2011. These figures included people who were not normally resident in their home villages but were still recognised (and paid) as members of the affected communities. Most of these absentees were living in urban areas in Western Province-especially the towns of Tabubil, Kiunga and Daru—and some had jobs associated with the mining operation. If the official national census figures from 2011 are reasonably accurate, this means that the 'CMCA people' accounted for 56 per cent of the population of Western Province in that year. The trust deeds and other institutional arrangements negotiated and renegotiated through the CMCA process produced a definition of the mine-affected area as one from which the 'non-CMCA people' in the original preferred area were now largely excluded. However, these villages were combined with all the other non-CMCA villages in Western Province as beneficiaries 
of what is officially (and rather confusingly) known as the 'non-CMCA region peoples trust account'. No such account has been established for the people of Telefomin District in West Sepik Province.

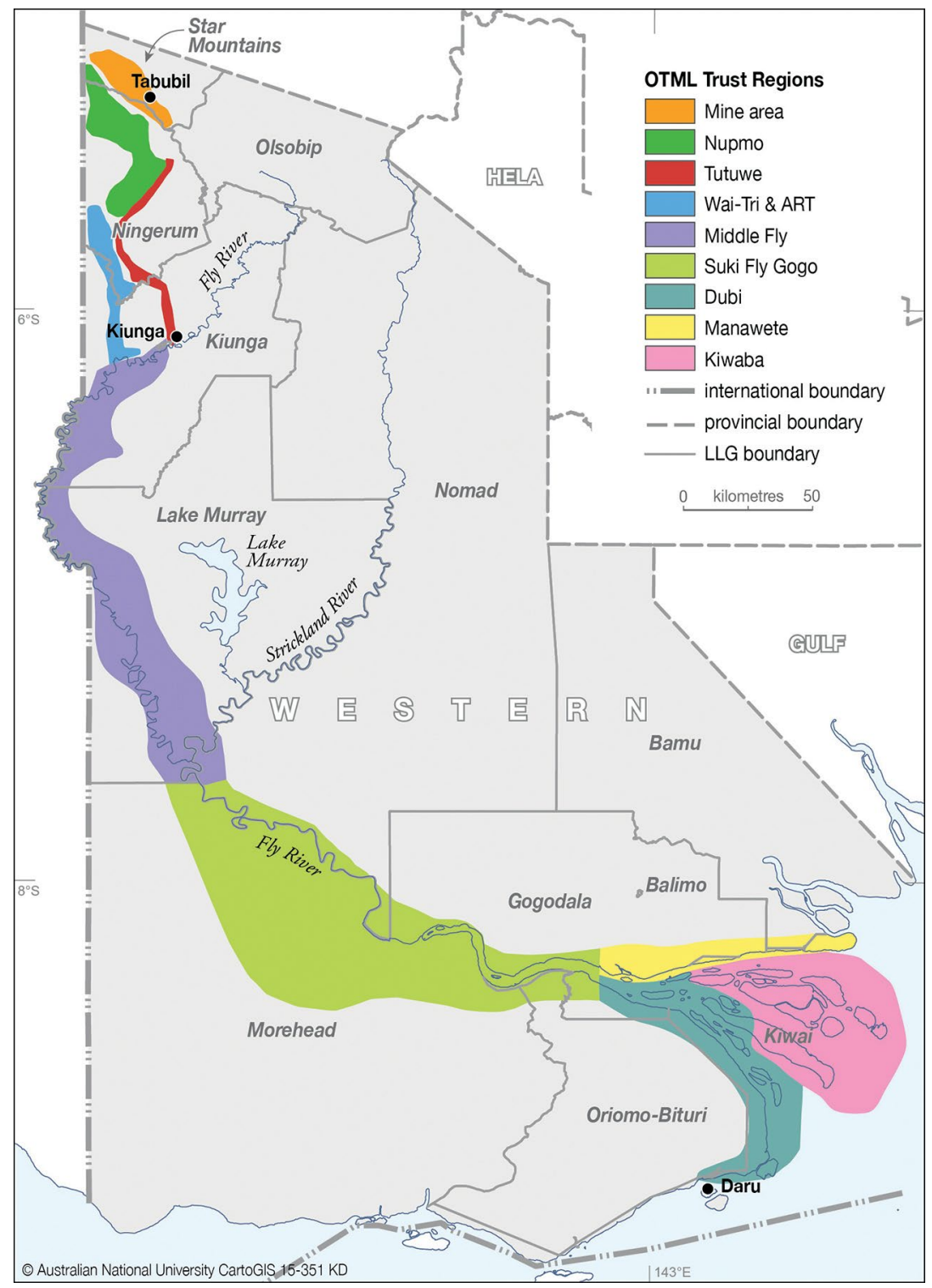

Figure 8.1 CMCA trust regions in Western Province.

Source: CartoGIS, The Australian National University. 
By 2007, the three districts of Western Province (North, Middle and South Fly) had been officially subdivided into 14 local-level government (LLG) areas under the terms of the Organic Law on Provincial Governments and Local-Level Governments 1995. Kiunga was one of three towns with its own local government, but Tabubil was treated as a single ward (with one local councillor) in the Star Mountains LLG area, which was one of 11 rural LLG areas in the province. The Star Mountains LLG area had 13 wards altogether, including the six 'mine area villages' and six other rural wards, some of which had previously been treated as part of the Ningerum area. If one compares a map of the CMCA trust regions with a map of the rural LLG boundaries in Western Province, it is evident that 9 of the 11 rural LLG areas contain some CMCA trust villages, but some of them contain a lot more than others. The internal divisions of the $\mathrm{Ok}$ Tedi proxy state have thus come to diverge from those of the official state, but those of the official state are in many ways less real than those of the proxy state because the institutions of the proxy state deliver most of the economic benefits which matter to the people of the mine-affected area, whatever its outer limits may be.

The institutions of the proxy state also do a better job of counting the number of people in the mine-affected area. According to the official national census, the whole of the Star Mountains LLG area, including the township of Tabubil, had a population of 15,458 in 2011. But an OTML survey of the 'Tabubil Plateau', which accounts for roughly half of that area, counted 23,071 residents in 2009 . Of these, 7,721 (33 per cent) were living in the town itself, 4,785 (21 per cent) in the six mine area villages (or council wards) and 10,565 (46 per cent) in a number of peri-urban squatter settlements whose populations seem to have been overlooked in the official census two years later. There is certainly no evidence of mass emigration (or eviction) from these settlements in the intervening period. It is also known that the population of the town may have been under-enumerated in the OTML survey because some of the residents were concealing the presence of 'unauthorised dependants'. So the real population of the Star Mountains LLG area in 2011 (including the six council wards formerly in the Ningerum area) was almost certainly in excess of 25,000. The official census counted 11,260 residents in Kiunga township in 2011, which is probably a more accurate number. The combined population of the two townships in 2011 would therefore have been more than 19,000, which suggests a 20 per cent increase over the urban population enumerated in 2000 . But what is almost certainly 
more significant is the parallel increase in the population of peri-urban settlements, especially around the township of Tabubil, which is the epicentre of the regional mining economy.

It is notable that the population of the six mine area villages was seven times greater in 2009 than it was 30 years earlier, before the start of mine construction. This was not the result of an extraordinary rate of natural increase, but was largely due to the immigration of people from other Mountain Ok (or Min) communities within the original preferred area, including parts of Telefomin District. About two-thirds of the people living in Tabubil town, and one-third of those living in the peri-urban settlements, also seem to have been born in the original preferred area. Some of these would have been 'CMCA people' from the Ningerum, Alice and Highway villages, but the proportion has not been established. In the 2009 survey, more than half of the 3,176 households on the Tabubil Plateau were found to contain at least one wage-earner, and most of the jobs they occupied were directly or indirectly dependent on the mine's continued operation. Even the households without a wage-earner, including 70 per cent of the households in the squatter settlements, had livelihoods that would be hard to sustain if the mine were to close.

\section{The Politics of Community Mine Continuation Agreements}

Section 8 of the Ninth Supplemental Agreement states that the 'signature or other execution' of a CMCA by a 'person representing or purporting to represent a Community or clan, or that person's delegate', binds all members of the group to the agreement, even if there is no 'express authority' for that person to represent the members of the group, or some group representatives have not signed the agreement, or some group members are not party to it. The same section then goes on to state that the real or purported group representative who signs or executes a CMCA binds all future members of the group to the agreement, even if they have not yet been born.

These clauses have attracted a good deal of critical academic scrutiny because of their apparent denial of what might normally be regarded as natural justice and human rights (Kirsch 2004, 2007; Kalinoe 2008). The powers they ascribed to individuals who might only be 'purporting' to represent all sorts of other people can partly be explained by the 
fact that some of these other people were unwilling to accept another big compensation package in return for a promise to desist from legal action against BHP. But the problematic framing of the social relations of representation in the mine-affected area can also be seen as a reflection of the long-standing difficulties faced by OTML staff, and even by 'real' government officials, in their efforts to manufacture consensus or consent in communities without strong leaders.

Interactions between OTML staff and members of downstream communities in the mine-affected area were already characterised by a politics of mutual distrust in the period following the establishment of the Lower Ok Tedi/Fly River Development Trust. The two sides to this relationship were equally unable to believe that the other side had anything other than a set of personal and political agendas that were unrelated to the actual impact of the mine on local livelihoods (Filer 1997: 78-9). In the years preceding the settlement of 1996, matters were complicated by the split between the two branches of the company that were responsible for community affairs and environmental management, each of which was holding separate talks with local villagers. Even after the settlement, company staff were concerned that talk about compensation for environmental damage was covering up the need for local communities to have their own plans and strategies for 'sustainable development' (Simpson 2002: 52). The legal and institutional separation of the OTDF from OTML's core business was seen by company management as an opportunity to address this problem, but the question of compensation was still central to the political process through which community members or their 'representatives' elected to opt in or out of the CMCAs between 2000 and 2002 (Kalinoe 2008: 7). However, the amount of politics in this process was substantially reduced by the absence of any opportunity for community representatives or members to negotiate the contents of the agreements (ibid.: 34).

Each of the six CMCAs made provision for the establishment of one or more community development foundations or trusts administered by OTML through the OTDF, with trustees from each of the villages represented in the agreement. ${ }^{2}$ The local trustees were to meet with their administrator once a quarter to decide how best to spend the 58 per cent of the K176 million compensation package that was earmarked for

2 It is not clear how the trustees were selected or appointed, or how many of them had been 'representative signatories' of the CMCAs in 2002. 
community development projects rather than cash payments or investments for future generations. It seems that OTML staff made a deliberate effort to avoid the appointment of local government ward councillors as local trustees, and thus created 'a whole new structure of community organisation and governance' (Kalinoe 2008: 10). At the lowest level of this new form of political organisation, the trustees would consult with 'village development committees' made up of 'village elders'. The consultation process has been described as one in which the trustees were 'required to go back to their village community and do patrols, possibly with OTML community relations officials, if not by themselves, and then inform their village community of the decision taken at the last trust meeting' (ibid.: 22). As a result, there was a tendency for them to be regarded by their own constituents as functionaries of the proxy state who were curiously removed from the realm of politics by means of a social contract that ruled out any talk of additional compensation beyond that which the 'communities' had already accepted (Crook 2004: 128).

If the original CMCAs can now be seen, in retrospect, as agreements between OTML and the PNG Government about the way that 'community consent' would be obtained for the continuation of mining operations, they did leave one space for community leaders or members to renegotiate the terms of that consent once they had purportedly given up their right to take further legal action. This was a requirement for the agreements to be reviewed after a period of five years. The company's senior managers decided that this constituted an opportunity for a 'fresh approach' to the business of negotiating community support, 'involving contemporary village leadership, as well as other interested stakeholders not already parties to the original agreement' (Offor and Sharp 2012: 217). At the same time, a fresh approach was needed because OTML's community relations staff were reporting a decline in the level of community support as benefits formerly anticipated had failed to materialise, even while the company's environmental scientists were projecting an increase in the scale and intensity of the environmental damage caused by mining operations (ibid.: 214).

The consultants engaged to design the review process have described the new approach as one that sought to establish an 'informed consensus' based on three 'guiding principles', namely: 'multi-party mediation; interestbased negotiation; and relationship-based communication' (Sharp and Offor 2008: 15; Offor and Sharp 2012: 214). The second and third of these principles were said to be 'culturally appropriate to the PNG setting 
as they are inherent in the Melanesian style and practice of negotiation in ordinary life' within a 'relationship-based culture' which has 'a firm view as to the longevity of an important relationship for the wellbeing of the community' (Sharp and Offor 2008: 19). An 'interest-based' negotiation was contrasted with one based on people's 'positions' within the political space constructed by previous actions and negotiations (Offor and Sharp 2012: 219).

The review process consisted of six three-day meetings of a working group comprising representatives of 15 groups of stakeholders over a period of 18 months in 2006 and 2007. Aside from the designers of the process, OTML also hired a collection of independent facilitators, advisers and observers to mediate between the different interests at play in the negotiations. The mine-affected communities were now divided between nine regions, rather than six, while separate representation was granted to 'women and youth' and to church organisations from within the mineaffected area, and to a national non-governmental organisation concerned with environmental matters. Community representation in the review process was based on the election of village representatives by village meetings 'supported' by OTML staff, and then on the appointment of three delegates to the working group by the village representatives elected from each of the nine regions (Offor and Sharp 2012: 218). Regional meetings of village representatives were held after the second working group meeting, meetings were held in all villages after the third working group meeting, and both types of meeting were reconvened after the final working group meeting in order to discuss and approve the outcome of the whole review process (ibid.: 221).

That outcome consisted of a compensation package worth K324 million over the seven years between 2007 and 2013 - the latter now scheduled as the year of mine closure-and a greater level of community participation in the design and management of development projects funded from this and other sources. Each of the nine 'regional communities' would also have a representative on a body advising the board of the OTDF, which would henceforth operate as the Ok Tedi and Fly River Development Program. This advisory body would not only have the power to vet all development project proposals, but would also appoint three 'associate directors' to the board to sit alongside the two directors representing OTML and the two directors representing SDP and the PNG Government respectively (Offor and Sharp 2012: 228). While OTML would still hold three of the four shares in the OTDF, and SDP would hold one 
share, one of the OTML shares was supposed to be transferred to a new representative body called the Ok Tedi Impact Area Association in 2012, one year before the anticipated date of mine closure. Despite the fact that there were no women among the village representatives involved in the review process, there was also an agreement that each of the representative bodies involved in implementing the new deal, from the OTDF board down to the level of 'village planning committees', would have to involve some female participation, and that 10 per cent of the benefits should be allocated to a Women and Children's Fund (Menzies and Harley 2012).

Despite the growing level of corporate investment in the production of an 'informed consensus' among the relevant stakeholders, the 'CMCA people' were still defined as the beneficiaries of the new deal, while responsibility for its delivery still fell to the employees of the OTML proxy state. The latter were still imbued with a 'technocratic ethos' that made it hard for them to 'do' community development, while the former were still failing to 'drive' their own community development because of internal wrangles about the structures of participation and representation. A survey of community attitudes to implementation of the new deal, five years after it had been concluded, found that local people still thought that the village planning committees failed to 'faithfully represent community interests' because the members were hoarding information or keeping benefits 'for their personal or family gain' (Menzies and Harley 2012: 7). Most of the committees were found to have only one female member, often a wife or other relative of the male chairman, and some of these chairmen were living in urban areas, not in the villages for which their plans were being made. The authors of this study found that 'intravillage politics' and 'elite capture' were still slowing down the delivery of 'community development' by the 'technocratic' agents of the proxy state, but the bureaucratic agencies of the real state were delivering even less, even though local members of the national parliament now had access to substantial 'constituency development funds'. 'Compounding this, the largely parallel CMCA governance structures are not linked to local government; thus village planning committees do not coordinate with ward development committees, and relations between the mine, Foundation, the PNG Sustainable Development Program, and the provincial government are a topic of continuing concern' (ibid.: 10). So 'politics' was conceived as a problem at every level of political organisation. 


\section{The Politics of the Mine Closure Planning Process}

Continuation and closure might seem like two sides of the same coin, but do not seem that way when considered as subjects of negotiation between local communities and the real or proxy state. While community representatives were drawn into a conversation about the mine's continuation at the time of the Ninth Supplemental Agreement, they were for many years excluded from a separate channel of communication through which OTML sought government approval for its own mine closure plans.

As we have seen, the World Bank cited the absence of a mine closure plan as one of the reasons for keeping the mine open after BHP decided to wash its hands of the operation in 2000. The need for such a plan had in fact been recognised ten years previously, when the national government made an undertaking to commission a 'long-term economic development plan' for what was then known as Tabubil District - an area which now comprises the Star Mountains and Olsobip LLG areas in the far north of Western Province. The Department of Finance and Planning made some effort to honour this commitment in 1993, with terms of reference that clearly related to the problem of mine closure, but a fiscal crisis consumed the money that would have been used to pay the consultants. By the time the plan was eventually drafted (Jackson 1999), its geographic scope had been made redundant by changes in the definition of the mine-affected area, so in that sense it was true that the company and the government had no plans to deal with the impact of mine closure on communities downstream of the mine.

By that time, the Department of Mining was already working on a new mine closure policy that called for the establishment of mine closure planning committees for each of the big mining projects that were already in operation. The Ok Tedi Mine Closure Planning Committee was established in 2000, and was meant to include representatives from OTML, the Fly River Provincial Government and five national government departments. Although the committee was notionally chaired by the Department of Mining, it was in effect a sounding board for plans made by the mining company. "While the MCPC [Mine Closure Planning Committee] members may commit to a plan there is no reason to believe, on the basis of past experience, that anyone other than OTML 
will follow the plan given that some of its recommendations are likely to be unpalatable to provincial politicians, the Administration and mineaffected communities' (Simpson 2002: 49). The likelihood that provincial politicians or members of mine-affected communities would object to the company's plans was somewhat diluted by the fact there were no provincial government or local community representatives on the committee when OTML produced the first of its new plans in 2002 (ibid.: 48).

The Ninth Supplemental Agreement required the company to establish a 'financial assurance fund' that would pay for the implementation of its mine closure plan, once this had been approved by the national government. In the meantime, the company was required to produce draft mine closure plans at two-yearly intervals, each time to be accompanied by 'a report on the social and economic impacts of mine closure and the status of economic programs being undertaken relevant to those impacts by the Company, the Ok Tedi Development Foundation, the Western Province Capacity Building Project, Government and other agencies'. The Western Province Capacity Building Project was itself funded by OTML under the terms of a separate agreement with the national government after the latter had stripped the Fly River Provincial Government of its financial powers in 1999 (Simpson 2002: 46; Kalinoe 2008: 40). In effect, this meant that the long arm of the proxy state had already reached into the field of provincial administration when the planning process got under way, and that helps to explain why the provincial administration was notable for its absence from the Mine Closure Planning Committee.

By 2005, when OTML's managing director brought numerous stakeholders together for a mine closure planning workshop at Tabubil, ${ }^{3}$ the provincial government was back in business, and the provincial planner sought to persuade the other workshop participants that the plans of OTML and SDP should henceforth be subordinated to the one that he had recently produced for Western Province as a whole. This looked even less likely than the prospect of collaboration between the two divisions of the proxy state, whose own plans bore no clear relationship to each other. But among the numerous stakeholders at the workshop, there were still none who directly represented the mine-affected communities. The community representatives (or at least some of them) held their own

3 One of us (Filer) was a participant observer at this workshop. 
meeting at Kiunga, where they showed much less enthusiasm for mine closure than OTML's managing director displayed in his address to the meeting at Tabubil.

The climax of the [Kiunga] meeting occurred when one of the speakers, using the call-and-response preaching style of public speaking that has become popular, called out to the participants, asking them, 'Do you want the environment or money?' Only a few people responded by saying 'environment'. There was a loud murmuring as the participants discussed the question among themselves. Finally, someone called out in Melanesian Pidgin, 'Tupela wantaim!' or 'Both of them at once', and the crowd loudly indicated its approval. In other words, they want to simultaneously protect the environment and have access to development opportunities and money. It is almost impossible for them to contemplate early mine closure when so much of the regional economy is dependent on its operation, and when so many of the villages have already been significantly affected by pollution and need the extra income provided by compensation payments to feed their families. They cannot imagine letting the mine close down without gaining some lasting form of economic benefit in return for all the damage that it has done to their environment. (Kirsch 2007: 314)

When OTML came to produce the third of its draft mine closure plans in 2006, the space that might have been occupied by a form of community consultation was already occupied by the CMCA review process, so if continuation and closure really were two sides of the same coin, each side had a distinctive group of stakeholders involved in a different type of conversation.

One thing that set the mine closure planning conversation apart from the mine continuation conversation was the uncertainty about when the mine would actually close. In 2001, at the time of the Ninth Supplemental Agreement, it was expected that the mine would close in 2010. Five years later, the moment of closure had been pushed back by two years. By 2009, one more year had been added to the mine's life expectancy, but the moment of closure was still coming closer. As OTML now faced the prospect of submitting a 'detailed' (and possibly final) mine closure plan to the national government, its new managing director decided that there was no longer room for two separate conversations about the future, but shortly afterwards he announced that consultations with 'Western provincial leaders' had opened up the possibility of postponing the moment of closure by another seven years (Anon. 2009). Two years later, the four politicians representing Western Province in the national parliament 
issued a joint statement demanding that the mine be closed in 2013, in accordance with the latest plan (Anon. 2011), but OTML countered this demand with the announcement of a Mine Life Extension Plan that would keep the mine in operation until 2022 or even 2025 (Hriehwazi 2011; Anon. 2012a). Local community support for this alternative plan was harnessed through a process of consultation that was understood to constitute the second review of the CMCAs. Representatives from each of the nine CMCA trust regions had signed up to the new deal by the end of 2012, five years after completion of the previous review (Anon. 2012b).

In September 2013, the government of Peter O'Neill enacted a Tenth Supplemental Agreement which deprived SDP of its majority stake in OTML and thus made the mining company a wholly state-owned enterprise. This action was justified by a claim that SDP's board of directors was not accountable to anyone but BHP Billiton. This set the scene for a protracted legal battle over property rights, with a specific focus on control of the 'long term fund' established under the terms of the Ninth Supplemental Agreement. The more immediate effect was to prevent OTML from making any further payments to SDP, which meant that the latter was obliged to shut down its operations and lay off its staff. At the same time, the national government acquired a much bigger financial stake in the continued operation of the mine, so long as it could still make a profit, and the prime minister seems to have thought that he now had more power to persuade the recalcitrant politicians of Western Province that mine continuation could serve their interests as well. As one of his spokesmen put it:

It is time for the CMCA leaders to work with their newly elected LLG leaders, their provincial government, and national leaders to ensure the new OTML and the new PNGSDP delivers the programs and projects that will go a long way in improving their lives and sustaining that for some time (Martin 2013).

Some of the 'CMCA leaders' objected to the nationalisation of the mine on the grounds that this was not a subject on which they had been consulted when they agreed to the Mine Life Extension Plan and, more importantly perhaps, because the national government was under no obligation to use any of the dividends derived from the shares formerly owned by SDP for the benefit of people in the mine-affected area. ${ }^{4}$ However, their right of

4 The legislation simply enabled the state 'to restructure PNGSDP and its operations to ensure that PNGSDP applies its funds for the exclusive benefit of the people of Western Province'. 
complaint was challenged by the president of the Ok Tedi Mine Impact Area Association, who claimed that his association was now the legitimate representative of all nine trust regions (Anon. 2013). There has not been an end to debate within Western Province on the timing of mine closure, and since there was a sharp fall in OTML's profits between 2012 and 2013, the national government may yet lose interest in extending the life of the mine.

\section{Conclusion}

Has the Ok Tedi proxy state operated like an 'anti-politics machine' that has sucked the lifeblood out of the real state in Western Province even at the same time that it has created a form of economic dependency that is inherently unsustainable? Have its engineers and mechanics managed to produce a semblance of community support for mine continuation that conceals the absence of traditional cultural and political institutions through which 'communities' could make any collective decisions about their future? Has the operation now reached a tipping point at which the number of politicians who sense an opportunity to seize control of money held in trust for mine-affected communities is more than a match for the number of technocrats or bureaucrats who have so far been charged with spending it on 'equitable and sustainable social and economic development'?

While we have done our best to summarise the evidence that might seem relevant to questions such as these, we do not think that it provides the answers. Even if we had more evidence, the answers would remain equivocal.

If the Fly River Provincial Government has failed the test of good governance throughout the life of the mining operation, this does not necessarily mean that it would have done a better job of providing public goods and services if the mine had never existed. Perhaps it makes more sense to assert that 'cultural attitudes have taken over the economic management of the province', and that is why the province has displayed a 'limitless capacity for "disappearing" any money given to it for development' (Burton 1998: 173). But this only leads us to another question, which is whether 'political culture' does more to explain the failure of the real state to deliver 'real development' in this province, as compared with other provinces, than do various measurable forms of 
poverty or backwardness that ought to be alleviated by the economic benefits of mining, but may have been exaggerated by the impact of mining on the physical environment. The concept of political culture bears an even bigger load if it is then used to explain the inability of communities or community leaders in the mine-affected area to negotiate a more sustainable or equitable compensation package (Burton 1997). But we might then wonder how that culture is related to the 'relationshipbased culture' that has been represented as something in which the mining company needs to participate if it wishes to secure community support for the maintenance of its own operations (Sharp and Offor 2008).

It is still a moot point whether the capacity of the Ok Tedi proxy state to secure this type of community support is a function of its capacity to understand and engage with the political culture of Western Province or its capacity to function as a substitute for the provincial government. The proxy state is clearly not a democratic state, so its engineers and mechanics do not have to satisfy the desires of the local population in order to keep their own jobs; they only have to satisfy their own superiors that they are doing something that is good for both the mining company and its mineaffected clients. From their point of view, 'local politics' or 'community attitudes' are liable to be seen as obstacles to the achievement of this goal, and not as things that need to be appreciated on the way. The social and political landscape of the mine-affected area is thus perceived as a twodimensional object, as flat as the flood plain of the Fly River, divided and subdivided into separate zones of entitlement to specific benefit streams whose dispensation is ideally free of any political interference.

There are two reasons to regard this as an optical illusion. The first is that the machinery of dispensation is nowhere near as efficient as the mills that churn up the rocks excavated from the remains of Mount Fubilan. The proxy state has been cobbled together from a disparate set of agreements with several government agencies and an assortment of 'community representatives'. With the passage of time it has become a sort of institutional jungle that lacks any mechanical or rational capacity to distribute money, goods or services in ways that are proportional to the impact of the mine or the needs of different groups of mine-affected people.

The second reason is that the growth of this institutional jungle has been matched by the continual enlargement of the 'mine-affected area' and the parallel detachment of a growing proportion of its resident 
population from livelihoods dependent on the land and natural resources contained within each zone of entitlement. There are still many villagers in the region who continue to make a living from what remains of their customary land, even when that land has been degraded by the impact of the mine, but the institutions of the proxy state may be no more accessible to such people than regular health and education services provided by the government or the churches. As the mining operation has matured, so has the tendency of rural 'community leaders' to gravitate towards the towns where they can mediate or manipulate the distribution of money, goods and services from all quarters. As a result, the superficial distinction between national, provincial and local-level politics, even in the operation of the 'anti-politics machine', has given way to a triangular relationship between elected and appointed leaders who spend various amounts of time in Port Moresby, Kiunga and Tabubil. ${ }^{5}$

Despite the efforts of the proxy state to produce a transparent process of 'community consultation' in the mine-affected area, it is this triangular urban space in which the political choice between mine closure and mine continuation must ultimately be negotiated. This choice is not quite as stark as it sometimes appears. Mine closure is normally a process in which operations gradually wind down before they finally cease altogether. In the present case, the process already began when OTML laid off a substantial proportion of its workforce at the end of 2013, and even if operations continue for another decade or more, the process could last much longer than it normally does because the institutional jungle contains a number of financial mechanisms designed to benefit the people of Western Province and the mine-affected area for many years after the mine itself has finally closed. With an ongoing decline in the proportion of people in the mine-affected area who make their living from wages paid by OTML or its contractors, we can safely anticipate a corresponding increase in the proportion whose primary economic interest lies in the distribution of what is broadly understood to be compensation for environmental damage. This, in turn, would seem to entail the disappearance of the demarcation lines that have previously separated positions of leadership in the real state and the proxy state. The battle for control of SDP can be understood as the start of this political process. Instead of assuming that the proxy state has somehow caused the real state to 'wither away', we may

5 Although Daru remains the official capital of Western Province, Kiunga is now the headquarters of the Fly River Provincial Government. 
now see that the real state has begun to consume the proxy state as the number of people employed to protect the latter from the former has also begun to fall.

Hitherto, the provincial governor and the three other members of the national parliament elected to represent the people of Western Province have been inclined to call for the mine to be closed sooner rather than later. This in itself does not seem to explain the frequency with which they have then gone on to lose their seats at the next national election, since their replacements have then made the same call. Although sometimes dressed in the language of environmental justice, their choices were more likely based on the resentment of their inability to control the operation of the proxy state and therefore use the promise of mine-related benefits to win over the hearts and minds of their constituents. In recent years, there has been a steady increase in the value of the 'constituency development funds' placed under the direct control of all members of parliament, and provision has recently been made for LLG presidents, who are now directly elected by their own constituents, to be granted their own share of the national development budget. One might suppose that this would give the elected politicians of Western Province less reason to push for control of the proxy state's own 'development budget', and yet the nationalisation of the mine seems to have changed the balance of incentives as well as the balance of power. ${ }^{6}$ It remains to be seen what new forms of social solidarity or political accountability might emerge in these new circumstances, but only a bold prophet would predict a more equitable or sustainable set of development outcomes any time soon.

\section{References}

Anon., 2009. 'Ok Tedi May Close in 2020.' Post-Courier, 30 June.

__, 2011. 'MPs: Ok Tedi Mine Must Close in 2013.' Post-Courier, 25 May.

__, 2012a. 'More Life at Ok Tedi.' Post-Courier, 8 March.

6 The newly elected provincial governor, Ati Wobiro, was formerly employed by SDP to manage its activities in Western Province. He openly supported the expropriation of his former employer but, unlike the re-elected member for North Fly District, he did not voice any public opposition to the Mine Life Extension Plan before he was found guilty of corruption and dismissed from office in 2016. 
— 2012b. 'Ok Tedi Villagers Approve of Mine's Extension.' The National, 31 December.

— 2013. 'Group Claims to Represent Community.' The National, 8 November.

Banks, G. and C. Ballard (eds), 1997. The Ok Tedi Settlement: Issues, Outcomes and Implications. Canberra: The Australian National University, National Centre for Development Studies (Pacific Policy Paper 27).

Burton, J., 1997. 'Terra Nugax and the Discovery Paradigm: How Ok Tedi Was Shaped by the Way It Was Found and How the Rise of Political Process in the North Fly Took the Company by Surprise.' In G. Banks and C. Ballard (eds), The Ok Tedi Settlement: Issues, Outcomes and Implications. Canberra: The Australian National University, National Centre for Development Studies (Pacific Policy Paper 27).

—_ 1998. 'Mining and Maladministration in Papua New Guinea.' In P. Larmour (ed.), Governance and Reform in the South Pacific. Canberra: The Australian National University, National Centre for Development Studies (Pacific Policy Paper 23).

Crook, T., 2004. 'Transactions in Perpetual Motion.' In E. Hirsch and M. Strathern (eds), Transactions and Creations: Property Debates and the Stimulus of Melanesia. New York: Berghahn Books.

Faulkner, K., 2005. 'Ok Tedi Project Update.' Unpublished presentation to Ok Tedi Mine Closure Planning Workshop, Tabubil, 28 October.

Filer, C., 1997. 'West Side Story: The State's and Other Stakes in the Ok Tedi Mine.' In G. Banks and C. Ballard (eds), The Ok Tedi Settlement: Issues, Outcomes and Implications. Canberra: The Australian National University, National Centre for Development Studies (Pacific Policy Paper 27).

_ 2005. 'The Role of Land-Owning Communities in Papua New Guinea’s Mineral Policy Framework.' In E. Bastida, T. Wälde and J. Warden-Fernández (eds), International and Comparative Mineral Law and Policy: Trends and Prospects. The Hague: Kluwer Law International. 
Filer, C., D. Henton and R. Jackson, 2000. Landowner Compensation in Papua New Guinea's Mining and Petroleum Sectors. Port Moresby: PNG Chamber of Mines and Petroleum.

Howes, S. and E. Kwa, 2011. 'Papua New Guinea Sustainable Development Program Review.' Report to PNG Sustainable Development Program Ltd.

Hriehwazi, Y., 2011. 'OTML Plans to Mine Till 2022.' The National, 3 October.

Jackson, R.T., 1979. 'The Awin: Free Resettlement on the Upper Fly River (Western Province).' In C.A. Valentine and B. Valentine (eds), Going through Changes: Villagers, Settlers and Development in Papua New Guinea. Boroko: Institute of Papua New Guinea Studies.

__, 1982. Ok Tedi: The Pot of Gold. Waigani: University of Papua New Guinea Press.

— - 1993. Cracked Pot or Copper Bottomed Investment? The Development of the Ok Tedi Project 1982-1991, a Personal View. Townsville: James Cook University (Melanesian Studies Centre).

__, 1999. 'The Tabubil Outline Longterm Economic Development Plan.' Unpublished report to the PNG Office of National Planning and Implementation and the PNG Department of Mineral Resources.

__ 2003. 'Muddying the Waters of the Fly: Underlying Issues or Stereotypes?' Canberra: The Australian National University, Research School of Pacific and Asian Studies, Resource Management in AsiaPacific Program (Working Paper 41).

Kalinoe, L., 2008. 'The Ok Tedi Mine Continuation Agreements: A Case Study Dealing with Customary Landowners' Compensation Claims.' Boroko (PNG): National Research Institute (Discussion Paper 105).

King, D., 1993. 'Statistical Geography of the Fly River Development Trust.' Waigani (PNG): Unisearch PNG Pty Ltd for Ok Tedi Mining Ltd (Ok-Fly Social Monitoring Project Report 4). 
, 1997. 'The Big Polluter and the Constructing of Ok Tedi: Ecoimperialism and Underdevelopment along the Ok Tedi and Fly Rivers of Papua New Guinea.' In G. Banks and C. Ballard (eds), The Ok Tedi Settlement: Issues, Outcomes and Implications. Canberra: The Australian National University, National Centre for Development Studies (Pacific Policy Paper 27).

Kirsch, S., 1989. 'The Yonggom, the Refugee Camps along the Border, and the Impact of the Ok Tedi Mine.' Research in Melanesia 13: 30-61.

_ 1995. 'Social Impact of the Ok Tedi Mine on the Yonggom Villages of the North Fly, 1992.' Research in Melanesia 19: 23-102.

—, 1997. 'Is Ok Tedi a Precedent? Implications of the Lawsuit.' In G. Banks and C. Ballard (eds), The Ok Tedi Settlement: Issues, Outcomes and Implications. Canberra: The Australian National University, National Centre for Development Studies (Pacific Policy Paper 27).

— 2004. 'Property Limits: Debates on the Body, Nature and Culture.' In E. Hirsch and M. Strathern (eds), Transactions and Creations: Property Debates and the Stimulus of Melanesia. New York: Berghahn Books.

— 2007. 'Indigenous Movementsand the RisksofCounterglobalization: Tracking the Campaign against Papua New Guinea’s Ok Tedi Mine.' American Ethnologist 34: 303-321.

Martin, M., 2013. 'Landowners Demand Shares.' Post-Courier, 26 September.

Menzies, N. and G. Harley, 2012. “'We Want What the Ok Tedi Women Have": Guidance from Papua New Guinea on Women's Engagement in Mining Deals.' Washington (DC): World Bank (J4P Briefing Note 7.2).

Offor, T. and B. Sharp, 2012. 'Turning a Benefit Agreement into Practical Development: A Case Study of a Papua New Guinea Development Foundation.' In M. Langton and J. Longbottom (eds), Community Futures, Legal Architecture: Foundations for Indigenous Peoples in the Global Mining Boom. Abingdon (UK): Routledge. 
OTML (Ok Tedi Mining Ltd), 1999. 'Mine Waste Management Project: Risk Assessment.' Unpublished report to the PNG Government.

Pintz, W., 1984. Ok Tedi: Evolution of a Third World Mining Project. London: Mining Journal Books.

Sharp, B. and T. Offor, 2008. 'Renegotiating a PNG Compensation Agreement: Applying an Informed Consensus Approach.' Canberra: The Australian National University, Research School of Pacific and Asian Studies, Resource Management in Asia-Pacific Program (Working Paper 69).

Simpson, G., 2002. 'Sustainable Development Policy and Sustainability Planning Framework for the Mining Sector in Papua New GuineaWorking Paper 6: Institutional Analysis.' Port Moresby: PNG Mining Sector Institutional Strengthening Project.

World Bank, 2000. 'Ok Tedi Mining Ltd Mine Waste Management Project: Risk Assessment and Supporting Documents.' Unpublished report to the PNG Government. 
This text is taken from Large-scale Mines and Local-level Politics: Between New Caledonia and Papua New Guinea, edited by Colin Filer and Pierre-Yves Le Meur, published 2017 by ANU Press, The Australian National University, Canberra, Australia. 